\section{Impact of Paclobutrazol on Root-pruned Live Oak}

\author{
Tomás Martínez-Trinidad ${ }^{1,3}$, W. Todd Watson², \\ and Russell K. Book ${ }^{2}$
}

ADDITIONAL INDEX wORDS. growth regulator, trench, vitality, nursery, Quercus virginiana

\begin{abstract}
Summary. This study evaluated the impact of paclobutrazol (PBZ) on the overall growth and vitality of root-pruned, field-grown live oak (Quercus virginiana). Live oak trees with $10-\mathrm{cm}$ trunk diameter (measured $30 \mathrm{~cm}$ aboveground) were treated with full rate $\left(0.8 \mathrm{~g} \cdot \mathrm{cm}^{-1}\right.$ trunk diameter) of $\mathrm{PBZ}$ as basal drenches, full or half rate $\left(0.8\right.$ or $0.4 \mathrm{~g} \cdot \mathrm{cm}^{-1}$ trunk diameter) of PBZ and trenching at $45 \mathrm{~cm}$ from trunk, full or half rate of PBZ and trenching at $60 \mathrm{~cm}$ from trunk, trenching alone at 45 or $60 \mathrm{~cm}$ from trunk, and only water. Trunk diameter and canopy growth was significantly reduced $(P<0.001)$ and new root growth was also reduced by applications of PBZ, root pruning, or both. Starch content in twigs decreased and glucose content increased on treatment by full-label rates of PBZ and root pruning at $60 \mathrm{~cm}$. PBZ and/or root pruning caused slight improvements in chlorophyll fluorescence (Fv/Fm). Results of this research indicate that $\mathrm{PBZ}$ (full rate) in combination with root pruning $(45 \mathrm{~cm})$ reduces tree growth and exhibits an overregulation effect for at least 16 months after treatment. Therefore, PBZ applications on root-pruned trees can temporarily decrease root and tree growth and improve foliage chlorophyll fluorescence.
\end{abstract}

$S$ everal studies have demonstrated that pruning roots can negatively impact growth and survivability of trees (Struve et al., 2000; Watson, 2004; Watson et al., 2000). A review of several studies on transplanted trees reveals that canopy growth can be stunted for several years after trees are transplanted (Haase and Rose, 1993; Johnson et al., 1984; Struve, 2009; Watson, 2000, 2005; Watson and Sydnor, 1987). In some cases, $85 \%$ to $95 \%$ of the rooting area is removed when trees are dug to be transplanted (Watson and Sydnor, 1987). The inability of trees to absorb water and nutrients and the loss of carbohydrate storage due to the removal of roots are largely responsible for the decrease in growth rate (Larimer and Struve, 2002; Struve et al., 2000). A similar phenomenon may be observed when

We thank Rainbow Treecare Scientific Advancements for funding this research, Shawn Bernick for technical expertise, Environmental Design, Inc. for donating and maintaining trees, the James M. Carder Endowed Fund of Excellence in Urban Forestry at Texas A\&M University, and The Consejo Nacional de Ciencia y Tecnologia CONACyT at México for funding academic studies. In addition, we thank Dudley Bernard and Lisbet IslasRodriguez who contributed to this study.

${ }^{1}$ Programa Forestal, Colegio de Postgraduados, Km. 36.5 Carr. Mex-Tex Montecillos, Texcoco Edo. de México 56230, México

${ }^{2}$ Department of Ecosystem Science and Management, Texas A\&M University, College Station, TX 778432138

${ }^{3}$ Corresponding author. E-mail: tomtz@colpos.mx. trenching severed roots on established trees in urban environments.

Various techniques have been suggested to improve survivability and promote recovery of root-pruned trees in nurseries and urban environments. Partial root pruning in field-grown trees before transplanting has been recommended as a cultural practice to improve the success of transplanting (Harris et al., 2004). Previous partial root pruning encouraged the growth of new fibrous roots within the root ball that was transplanted along with the tree (Watson and Sydnor, 1987). Although some studies have recommended removing a portion of the canopy to compensate for the root loss (Watson, 1998), other studies have suggested that it is better to avoid canopy pruning to take advantage of the leaves and storage tissues on the branches, which may produce carbohydrates necessary for the regeneration of new roots (Struve et al., 2000). It is believed that survival and recovery of newly planted trees or large trenched trees greatly depend on rapid root growth, so that the plant regains the ability to absorb water from the soil (Harris et al., 2004).

It might be beneficial for trees if the retained canopy could be treated to reduce transpiration. Antitranspirants have been used with varying levels of success (Harris et al., 2004). However, most antitranspirants clog the stomates in the leaves, which could reduce photosynthesis and the production of carbohydrates necessary for root growth (Pallardy, 2008). Instead of pruning the canopy to balance the root:shoot ratio or using antitranspirants to conserve moisture, the use of growth regulators might be a viable option to improve the health of damaged or rootpruned transplants as they can reduce transpiration, promote photosynthesis, conserve carbohydrates, and promote root growth (Watson, 2000, 2001).

Paclobutrazol is a gibberellininhibiting tree growth regulator that can be applied as a basal soil drench, which is absorbed by roots and translocated through the vascular system to the canopy (Couture, 1982). Paclobutrazol has been shown to reduce the growth of canopy and trunk diameter of several tree species (Bai et al., 2004; George and Nissen, 2002; Grochowska et al., 2004; Keever et al., 1990; Singh, 2000; Sperry and Chaney, 1999; Williams et al., 2003). This growth reduction appears to conserve carbohydrates that can be stored or used for other physiological functions in the plant. Paclobutrazol also increases production of chlorophyll, which may improve or prolong carbohydrate production (Percival and Salim-AlBulushi, 2007). Additionally, PBZ has been shown to increase the ability of trees to resist both abiotic and biotic stresses (Navarro et al., 2007; Percival and Salim-AlBulushi, 2007). Root growth

\begin{tabular}{lllc}
\hline $\begin{array}{l}\text { Units } \\
\text { To convert U.S. to SI, } \\
\text { multiply by }\end{array}$ & U.S. unit & SI unit & $\begin{array}{l}\text { To convert SI to U.S., } \\
\text { multiply by }\end{array}$ \\
\hline 29.5735 & $\mathrm{fl} \mathrm{oz}$ & $\mathrm{mL}$ & 0.0338 \\
0.3048 & $\mathrm{ft}$ & $\mathrm{m}$ & 3.2808 \\
0.0929 & $\mathrm{ft}^{2}$ & $\mathrm{~m}^{2}$ & 10.7639 \\
2.54 & inch $(\mathrm{es})$ & $\mathrm{cm}$ & 0.3937 \\
25.4 & inch $(\mathrm{es})$ & $\mathrm{mm}$ & 0.0394 \\
0.4882 & $\mathrm{lb} / 1000 \mathrm{ft}^{2}$ & $\mathrm{~kg} / 100 \mathrm{~m}^{2}$ & 2.0482 \\
11.1612 & $\mathrm{oz} / \mathrm{inch}$ & $\mathrm{g} \cdot \mathrm{cm}^{-1}$ & 0.0896 \\
0.001 & $\mathrm{ppm}$ & $\mathrm{mg} \cdot \mathrm{g}^{-1}$ & 1000
\end{tabular}


of some trees can be enhanced by PBZ (Watson, 2000). An increase in fine roots as a result of PBZ application may improve tree recovery after roots have been cut (Watson, 2004).

The objective of this research was to examine the impact of PBZ, when applied with root pruning, on the overall growth and vitality of fieldgrown live oak tree roots pruned at two distances from the tree.

\section{Materials and methods}

The research was conducted in a commercial tree farm at Monaville, TX (lat. $29^{\circ} 57^{\prime} 1.59^{\prime \prime} \mathrm{N}$, long. $\left.96^{\circ} 3^{\prime 2} 28.73^{\prime \prime} \mathrm{W}\right)$. Forty field-grown live oaks $\approx 10 \mathrm{~cm}$ in diameter were randomly selected within the tree nursery. Tree trunks were measured $30 \mathrm{~cm}$ above the ground. Untreated, buffer trees surrounded every experimental tree on all sides of the tree. The soil was deep, moderately well-drained, slowly permeable Lake Charles clay. The upper soil horizon was acidic $(\mathrm{pH}$ 6.3 ), but alkalinity increased uniformly with depth ( $\mathrm{pH} 7.8-8.2$ at $1.5 \mathrm{~m})$. Trees were drip irrigated (Netafim, Fresno, CA) as required and fertilized annually with $5 \mathrm{~kg} / 100 \mathrm{~m}^{2} 20 \mathrm{~N}-8.7 \mathrm{P}-$ 16.6K (Nelson Plant Food, Bellville, TX). Trees appeared healthy with no visible symptoms of environmental or cultural stress.

Paclobutrazol applications consisted of basal drenches around the tree trunks with Cambistat ${ }^{\circledR}$ (Rainbow Treecare Scientific Advancements, St. Louis Park, MN) using label recommendation of $0.8 \mathrm{~g} \cdot \mathrm{cm}^{-1}$ trunk diameter. In May 2005, PBZ was applied at full or half rate diluted with water. Treatments consisted of 1) control, 2) full rate PBZ alone, 3 ) full rate PBZ and trenching at $45 \mathrm{~cm}$ from trunk, 4) half rate $\mathrm{PBZ}$ and trenching at $45 \mathrm{~cm}$ from trunk, 5 ) full rate PBZ and trenching at $60 \mathrm{~cm}$ from trunk, 6) half rate PBZ and trenching at $60 \mathrm{~cm}$ from trunk, 7) trenching alone at $45 \mathrm{~cm}$ from trunk, and 8) trenching alone at $60 \mathrm{~cm}$ from trunk. The trenches were dug around the perimeters of the trees at the specified distance to a depth of $60 \mathrm{~cm}$ with the assistance of a walkbehind trencher to ensure that the vast majority of the roots were confined to the pruned distance. After using the trencher, finer cuts were made on larger roots, and the excavated soil was immediately backfilled into trenches to avoid any potential for air pruning.
Trunk diameters were measured quarterly at $30 \mathrm{~cm}$ above soil for 16 months after treatments because the effect of growth retardant usually becomes evident during the next growth season. Canopy growth was assessed by using digital photography. Digital pictures were taken at two known points $45^{\circ}$ apart and $6 \mathrm{~m}$ away from each tree before treatments. The pictures were taken again after 16 months and compared with the original pictures to determine changes in overall canopy growth using the software ImageJ (Abramoff et al., 2004; MartinezTrinidad et al., 2009a).

Root growth was evaluated by collecting four soil cores $(15 \mathrm{~cm}$ deep $\times$ $6 \mathrm{~cm}$ diameter) using a core sampler (AMS, American Fall, ID) at $0.5 \mathrm{~m}$ from the trunk of each tree in the four cardinal directions around the tree. Each hole was backfilled with sandy soil and resampled 16 months after treatments to measure new root growth. Herbicide (glyphosate) was applied periodically at label rates during the experiment to eliminate weeds. Length and diameter of root samples were analyzed using the WinRhizo software (Regent Instruments, Quebec City, QC, Canada).

Carbohydrate levels were also measured because there is no information on the effect of PBZ on carbohydrates for live oak. One-year twig samples were collected to analyze glucose and starch content every 4 months. Samples were collected from the lower twothirds of the canopy on each tree. Glucose and starch contents were determined using GAGO-20 reagents (Sigma, St. Louis, MO). Glucose was extracted from tissue with methanol: chloroform:water (12:5:3 by volume) solution after centrifugation at $2800 \mathrm{~g}$. A $0.5-\mathrm{mL}$ aliquot of the extract and the glucose standards were mixed with $5 \mathrm{~mL}$ of anthrone reagent. Starch content was determined in the remaining pellet using the enzyme amyloglucosidase. Absorbance of samples and standards was read within $30 \mathrm{~min}$ by using a spectrophotometer (Spectronic 20; Baush \& Lomb, Rochester, NY) set at $625 \mathrm{~nm}$ for glucose and $540 \mathrm{~nm}$ for starch (Martinez-Trinidad et al., 2009a).

Chlorophyll fluorescence was measured on 10 leaves of the lower two-thirds of the canopy using a portable fluorescence spectrometer (HandyPEA; Hansatech Instruments, King's Lynn, UK). The measurements were evaluated with a biolyzer program (Percival et al., 2006). Ten leaves from the lower two-thirds of the canopy were adapted to darkness by attaching exclusion clips on the leaf surface (Martinez-Trinidad et al., 2009b; Percival and Fraser, 2005). Preliminary tests indicated that the time necessary to achieve leaf dark adaptation was $25 \mathrm{~min}$.

The experimental design was completely randomized (eight treatments with five replicates), and the data were analyzed with the procedure general linear model using SPSS (version 13 for Windows; SPSS Inc., Chicago, IL). When the main factors were significant $(P<0.05)$, multiple mean comparisons were made between treatments using Tukey's honestly significant difference test $(\alpha=0.05)$.

\section{Results and discussion}

Canopy growth was significantly reduced $(P<0.001)$ by the applications of PBZ, PBZ with root pruning, and root pruning alone (Table 1 ). Increases in the amount of roots pruned and the amount of PBZ applied resulted in marked decreases in tree trunk and canopy growth. Similar tendencies were found in earlier research on newly planted live oak treated with PBZ (Gilman, 2004), where the canopy growth was mainly affected by the application of PBZ alone or together with root pruning. The effect was most evident on trees treated with the full rate of PBZ and root pruned at $45 \mathrm{~cm}$ (Figs. 1 and 2). A similar result was found on trunk growth or canopy growth in species such as white oak (Quercus alba), red oak (Quercus rubra), cherrybark oak (Quercus falcata var. pagodaefolia), and american elm (Ulmus americana) (Bai et al., 2004; Watson, 2001). The average reduction in canopy growth was $\approx 22 \%$ to $66 \%$ in this study, which is the range reported for other species of hardwoods (Arron et al., 1997; Bai et al., 2004; Jacyna, 2007; Sperry and Chaney, 1999; Wheeler, 1987). Shoot growth was decreased in the seedlings of american elm treated with root pruning and PBZ under greenhouse conditions. However, treatments with lower PBZ rates did not produce a significant effect (Watson, 2001). It is important to note from our study and from precautions on the Cambistat label that PBZ rates need to be reduced, depending on the severity of 
Table 1. Growth variables (trunk and canopy increment and new root length and diameter) of live oak treated with paclobutrazol (PBZ) at 0.8 or $0.4 \mathrm{~g} \cdot \mathrm{cm}^{-1}$ trunk diameter $(0.072$ or $0.036 \mathrm{oz} / \mathrm{inch})$ and/or root pruning at 45 or $60 \mathrm{~cm}(17.7 \mathrm{or}$ 23.6 inches) from the trunk 16 months after treatments.

\begin{tabular}{|c|c|c|c|c|}
\hline$\underline{\text { Treatment }}$ & $\begin{array}{c}\text { Trunk } \\
\text { increment } \\
(\mathrm{cm})^{\mathrm{z}}\end{array}$ & $\begin{array}{c}\text { Canopy } \\
\text { increment } \\
\left(\mathrm{m}^{2}\right)^{\mathrm{y}}\end{array}$ & $\begin{array}{l}\text { Root } \\
\text { length } \\
(\mathrm{mm})^{\mathrm{x}}\end{array}$ & $\begin{array}{l}\text { Root } \\
\text { diam } \\
(\mathrm{mm}) \\
\end{array}$ \\
\hline Control & $1.14 \mathrm{a}^{\mathrm{w}}$ & $0.84 \mathrm{a}$ & $101 \mathrm{a}$ & $0.92 \mathrm{a}$ \\
\hline $\operatorname{PBZ}\left(0.8 \mathrm{~g} \cdot \mathrm{cm}^{-1}\right)$ & $0.88 \mathrm{~b}$ & $0.52 \mathrm{bc}$ & $75 \mathrm{~b}$ & $0.58 \mathrm{~b}$ \\
\hline $\begin{array}{l}\text { PBZ }\left(0.8 \mathrm{~g} \cdot \mathrm{cm}^{-1}\right)+\text { root } \\
\text { pruning }(45 \mathrm{~cm})\end{array}$ & $0.44 \mathrm{c}$ & $0.32 \mathrm{c}$ & $38 \mathrm{~cd}$ & $0.24 \mathrm{bc}$ \\
\hline $\begin{array}{l}\text { PBZ }\left(0.8 \mathrm{~g} \cdot \mathrm{cm}^{-1}\right)+\text { root } \\
\text { pruning }(60 \mathrm{~cm})\end{array}$ & $0.60 \mathrm{c}$ & $0.46 \mathrm{c}$ & $40 \mathrm{~cd}$ & $0.29 \mathrm{bc}$ \\
\hline $\begin{array}{l}\text { PBZ }\left(0.4 \mathrm{~g} \cdot \mathrm{cm}^{-1}\right)+\text { root } \\
\text { pruning }(45 \mathrm{~cm})\end{array}$ & $0.70 \mathrm{bc}$ & $0.54 \mathrm{bc}$ & $50 \mathrm{c}$ & $0.42 \mathrm{c}$ \\
\hline $\begin{array}{l}\text { PBZ }\left(0.4 \mathrm{~g} \cdot \mathrm{cm}^{-1}\right)+\text { root } \\
\text { pruning }(60 \mathrm{~cm})\end{array}$ & $0.62 \mathrm{c}$ & $0.62 \mathrm{~b}$ & $30 \mathrm{~d}$ & $0.25 \mathrm{c}$ \\
\hline Root pruning $(45 \mathrm{~cm})$ & $0.96 \mathrm{ab}$ & $0.80 \mathrm{a}$ & $52 \mathrm{bc}$ & $0.42 \mathrm{c}$ \\
\hline Root pruning $(60 \mathrm{~cm})$ & $0.84 \mathrm{~b}$ & $0.76 \mathrm{ab}$ & $35 \mathrm{~cd}$ & $0.31 \mathrm{c}$ \\
\hline
\end{tabular}

${ }^{2}$ Diameter measured at $30 \mathrm{~cm}$ above ground; $1 \mathrm{~cm}=0.3937$ inch.

yCanopy growth assessed through the use of vertical digital photos; $1 \mathrm{~m}^{2}=10.7639 \mathrm{ft}^{2}$.

From soil cores at $0.5 \mathrm{~m}(1.64 \mathrm{ft})$ from the trunk; $1 \mathrm{~mm}=0.0394$ inch.

${ }^{w}$ Means within columns not followed by the same letter are significantly different at $P \leq 0.05$ using Tukey's honestly significant difference test.
A

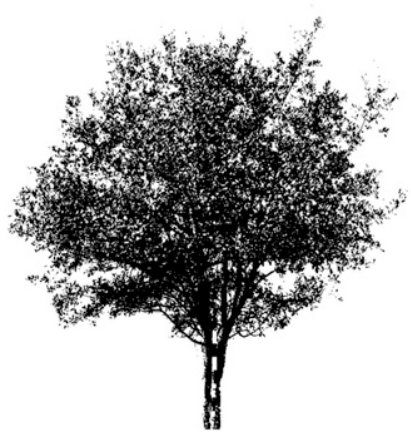

B

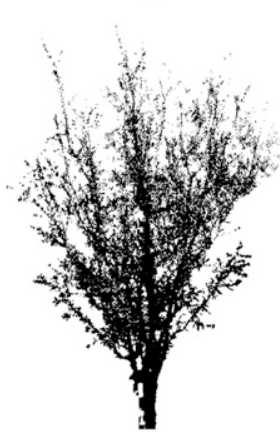

C

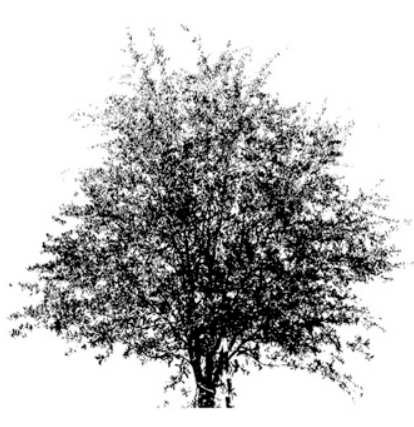

Fig. 1. Tree canopy growth of live oak treated with control (A), paclobutrazol at $0.8 \mathrm{~g} \cdot \mathrm{cm}^{-1}$ trunk diameter $(0.072 \mathrm{oz} / \mathrm{inch})$ and root pruning at $45 \mathrm{~cm}(17.7$ inches) from the trunk (B), and root pruning alone at $45 \mathrm{~cm}$ from the trunk $(\mathrm{C})$ 16 months after treatments.
A

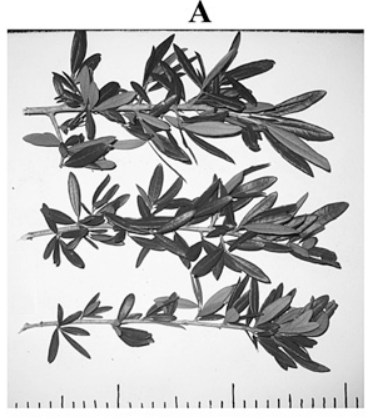

B

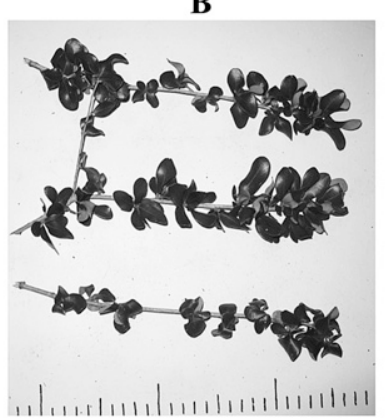

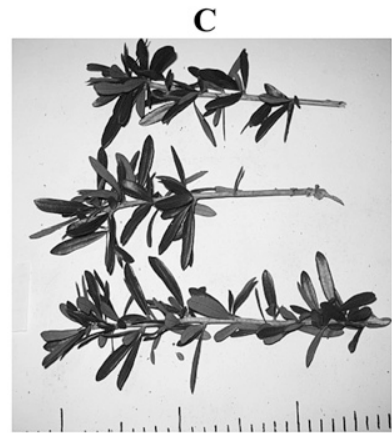

Fig. 2. Close up of leaves of live oak treated with control (A), paclobutrazol at $0.8 \mathrm{~g} \cdot \mathrm{cm}^{-1}$ trunk diameter $(0.072 \mathrm{oz} / \mathrm{inch})$ and root pruning at $45 \mathrm{~cm}(17.7$ inches $)$ from the trunk $(B)$, and root pruning alone at $45 \mathrm{~cm}$ from the trunk $(C)$ 16 months after treatments. root removal, to avoid overregulation of tree growth.

Previous research showed how canopy and trunk growth of red oak and pin oak (Quercus palustris) decrease after transplanting (Struve et al., 2000; Watson, 1998); however, rootpruned trees alone in this study did not have a decrease in canopy growth, but a decrease in trunk growth. This might be because of a substantial number of uncut roots beneath the root balls.

In the case of new root growth, trees treated with PBZ exhibited a reduction in the length and diameter of new roots, although the results were affected by large variability among data (Table 1). Preceding research indicated that a large reduction in canopy growth resulted in decreased root growth (Harris et al., 2004; Watson, 2001). Research has also shown either an increase or no effect on root density (Watson, 2000, 2004, 2006).

Starch content in trees treated with PBZ, root pruning, or half rates and root pruning were not different from that in the controls (Table 2). Similar results were found with starch content in the roots of white oak treated with PBZ (Watson, 2006). On the contrary, the treatment with full label rates and root pruning at 45 and $60 \mathrm{~cm}$ showed counteractive effects in starch and glucose, indicating that excessive root pruning associated with PBZ application can affect the carbohydrate reserves on trees. For example, those trees treated with PBZ and root pruning at $60 \mathrm{~cm}$ showed an increase in glucose content, but showed a reduction in starch content. Previous research has shown how carbohydrate content of different plant tissues has been increased by PBZ application (Watson, 2001). Even when PBZ overregulated leaf growth (Fig. 2), the potential effect on increased chlorophyll production might overcome the overall production of carbohydrates on tissues (Percival and Salim-AlBulushi, 2007). Research has also shown how higher glucose and starch contents in trees can be used as indicators of greater tree vitality of live oak (MartinezTrinidad et al., 2009b).

Trees treated with PBZ tend to have higher chlorophyll fluorescence values caused probably by the promotion of chlorophyll production or simply by the concentration of the same amount of chlorophyll in a smaller volume of leaf tissue. Percival and 
Table 2. Carbohydrate (glucose and starch) content in twigs and chlorophyll fluorescence of live oak treated with paclobutrazol (PBZ) at 0.8 or $0.4 \mathrm{~g} \cdot \mathrm{cm}^{-1}$ trunk diameter $(0.072$ or $0.036 \mathrm{oz} / \mathrm{inch})$ and/or root pruning at 45 or $60 \mathrm{~cm}$ (17.7 or 23.6 inches) from the trunk 16 months after treatments.

\begin{tabular}{|c|c|c|c|}
\hline Treatment & $\begin{array}{l}\text { Twig glucose } \\
\text { content } \\
\left(\mathrm{mg} \cdot \mathrm{g}^{-1} \text { dry wt }\right)^{\mathrm{z}}\end{array}$ & $\begin{array}{c}\text { Twig starch } \\
\text { content } \\
\left(\mathrm{mg} \cdot \mathrm{g}^{-1} \text { dry wt) }\right.\end{array}$ & $\begin{array}{c}\text { Chlorophyll } \\
\text { fluorescence } \\
\text { (Fv/Fm) } \\
\end{array}$ \\
\hline Control & $31.72 b^{y}$ & $10.16 \mathrm{~b}$ & $0.69 \mathrm{~cd}$ \\
\hline $\operatorname{PBZ}\left(0.8 \mathrm{~g} \cdot \mathrm{cm}^{-1}\right)$ & $31.99 \mathrm{~b}$ & $10.65 \mathrm{~b}$ & $0.73 \mathrm{~b}$ \\
\hline $\begin{array}{l}\text { PBZ }\left(0.8 \mathrm{~g} \cdot \mathrm{cm}^{-1}\right)+\text { root } \\
\text { pruning }(45 \mathrm{~cm})\end{array}$ & $30.37 \mathrm{c}$ & $11.65 \mathrm{a}$ & $0.74 \mathrm{~b}$ \\
\hline $\begin{array}{l}\operatorname{PBZ}\left(0.8 \mathrm{~g} \cdot \mathrm{cm}^{-1}\right)+\text { root } \\
\text { pruning }(60 \mathrm{~cm})\end{array}$ & $32.99 \mathrm{a}$ & $9.09 \mathrm{c}$ & $0.75 \mathrm{a}$ \\
\hline $\begin{array}{l}\text { PBZ }\left(0.4 \mathrm{~g} \cdot \mathrm{cm}^{-1}\right)+\text { root } \\
\text { pruning }(45 \mathrm{~cm})\end{array}$ & $31.26 \mathrm{~b}$ & $10.62 \mathrm{~b}$ & $0.72 \mathrm{bc}$ \\
\hline $\begin{array}{l}\mathrm{PBZ}\left(0.4 \mathrm{~g} \cdot \mathrm{cm}^{-1}\right)+\text { root } \\
\quad \text { pruning }(60 \mathrm{~cm})\end{array}$ & $31.99 \mathrm{~b}$ & $10.10 \mathrm{~b}$ & $0.71 \mathrm{c}$ \\
\hline Root pruning $(45 \mathrm{~cm})$ & $30.13 \mathrm{c}$ & $10.45 \mathrm{~b}$ & $0.70 \mathrm{c}$ \\
\hline Root pruning $(60 \mathrm{~cm})$ & $30.38 c$ & $10.34 \mathrm{~b}$ & $0.68 \mathrm{~d}$ \\
\hline
\end{tabular}

${ }^{\mathrm{z}} \mathrm{l} \mathrm{mg} \cdot \mathrm{g}^{-1}=1000 \mathrm{ppm}$.

y Means within columns not followed by the same letter are significantly different at $P \leq 0.05$ using Tukey's honestly significant difference test.

Salim-AlBulushi (2007) indicate that PBZ moves to the subapical meristem and affects the pathway of gibberellic acid and increases the production of abscisic acid and chlorophyll. It seems that PBZ applications can promote increased tree vitality as higher chlorophyll fluorescence values $\mathrm{Fv} / \mathrm{Fm}$ have been used as an indication of greater tree vitality (Martinez-Trinidad et al., 2009b; Percival and Fraser 2005).

Results of this research indicate that PBZ in combination with root pruning has a negative impact on tree growth 16 months after treatment. The growth-retarding effect of PBZ after root pruning might reduce transplant shock of newly planted trees or decline of mature trees with construction-related damage to the roots by reducing shoot:root ratios. The reduction in canopy size can improve tree vitality, which was corroborated with carbohydrate content and chlorophyll fluorescence results. These results were obtained from small trees, and so larger trees may not be as severely affected when treated at the recommended label rates.

\section{Literature cited}

Abramoff, M.D., P.J. Magelhaes, and S.J. Ram. 2004. Image processing with ImageJ. Biophotonics Intl. 11:36-42.

Arron, G.P., S. de Becker, H.A. Stubbs, and E.W. Szeto. 1997. An evaluation of the efficacy of tree growth regulators paclobutrazol flurprimido, dikegulac, and uniconazole for utility line clearance. J. Arboriculture 23:8-16.

Bai, S., W. Chaney, and Y. Qi. 2004. Response of cambial and shoot growth in trees treated with paclobutrazol. J. Arboriculture 30:137-145.

Couture, R. 1982. A new experimental growth regulator from ICI. Proc. Growth Regulat. Soc. Amer. 9:59.

George, A.P. and R.J. Nissen. 2002. Control of tree size and vigor in custard apple (Annona spp. hybrid) cv. African Pride in subtropical Australia. Aust. J. Expt. Agr. 42: 503-512.

Gilman, E.F. 2004. Effects of amendments, soil additives, and irrigation on tree survival and growth. J. Arboriculture 30:301-310.

Grochowska, M.J., M. Hondun, and A. Mika. 2004. Improving productivity of four fruit species by growth regulators applied once in ultra-low doses to the collar. J. Hort. Sci. Biotechnol. 79:252259.

Haase, D.L. and R. Rose. 1993. Soil moisture stress induces transplant shock in stored and unstored $2+0$ douglas-fir seedlings of varying root volumes. For. Sci. 39:275-294.

Harris, R.W., J.R. Clark, and N.P. Matheny. 2004. Arboriculture: Integrated management of landscape trees, shrubs, and vines, 4th ed. Prentice Hall, Upper Saddle River, NJ.

Jacyna, T. 2007. Effects of paclobutrazol applied to tree bark on performance of sweet cherry and apparent soil residue. J. Hort. Sci. Biotechnol. 82:19-24.
Johnson, P.S., S.L. Novinger, and W.G. Mares. 1984. Root, shoot, and leaf area growth potentials of northern red oak planting stock. For. Sci. 30:1017-1026.

Keever, G.J., W.J. Foster, and J.C. Stephenson. 1990. Paclobutrazol inhibits growth of woody landscape plants. J. Environ. Hort. 8:41-47.

Larimer, J. and D.K. Struve. 2002. Growth, dry weight, and nitrogen distribution of red oak and 'Autumn flame' red maple under different fertility levels. J. Environ. Hort. 20:28-35.

Martinez-Trinidad, T., W.T. Watson, M.A. Arnold, and L. Lombardini. 2009a. Investigations of exogenous applications of carbohydrates on the growth and vitality of live oaks. Urban For. Urban Green. 8: 41-48.

Martinez-Trinidad, T., W.T. Watson, M. Arnold, L. Lombardini, and D.N. Appel. 2009b. Carbohydrate injections as a potential option to improve growth and vitality of live oaks. Arboriculture Urban For. 35:142-147.

Navarro, A., M.J. Sanchez-Blanco, and S. Bañon. 2007. Influence of paclobutrazol on water consumption and plant performance of Arbutus unedo seedlings. Sci. Hort. 111:133-139.

Pallardy, S.G. 2008. Physiology of woody plants. 3rd ed. Academic Press, New York.

Percival, G.C. and G.A. Fraser. 2005. Use of sugars to improve root growth and increase transplant success of birch (Betula pendula Roth). J. Arboriculture 31:66-77.

Percival, G.C., I.P. Keary, and S. Al-Habsi. 2006. An assessment of the drought tolerance of Fraxinus genotypes for urban landscape plantings. Urban For. Urban Green. 15:17-27.

Percival, G.C. and A.M. Salim-AlBulushi. 2007. Paclobutrazol-induced drought tolerance in containerized english and evergreen oak. Arboriculture Urban For. 33:397-409.

Singh, Z. 2000. Effects of (2RS, 3RS) paclobutrazol on tree vigour, flowering, fruit set and yield in mango. Acta Hort. 525:459-462.

Sperry, C.E. and W.R. Chaney. 1999. Tree growth regulator effect on phototropism-its implications for utility forestry. J. Arboriculture 25:43-47.

Struve, D.K. 2009. Tree establishment: A review of some of the factors affecting transplant survival and establishment. Arboriculture Urban For. 35:10-13.

Struve, D.K., L. Burchfield, and C. Maupin. 2000. Survival and growth of transplanted 


\section{Research Reports}

large- and small-caliper red oaks. J. Arboriculture 26:162-169.

Watson, G.W. 1998. Tree growth after trenching and compensatory crown pruning. J. Arboriculture 24:47-53.

Watson, G.W. 2000. Tree root system enhancement with paclobutrazol, p. 131-135. In: A. Stokes (ed.). The supporting roots of trees and woody plants: Form, function and physiology. Kluwer Academic Publishers, Dordrecht, The Netherlands.

Watson, G.W. 2001. Soil applied paclobutrazol affects root growth, shoot growth, and water potential of american elm seedlings. J. Environ. Hort. 19:119-122.
Watson, G.W. 2004. Effect of transplanting and paclobutrazol on root growth of 'green column' black maple and 'summit' green ash. J. Environ. Hort. 22:209-212.

Watson, G.W. 2006. The effect of paclobutrazol treatment on starch content, mycorrhizal colonization, and fine root density of white oaks (Quercus alba L.). Arboriculture Urban For. 32:114-117.

Watson, G.W. and T.D. Sydnor. 1987. The effect of root pruning on the root system of nursery trees. J. Arboriculture 13:126-130.

Watson, W.T. 2005. Influence of tree size on transplant establishment and growth. HortTechnology 15:118-122.
Watson, W.T., M.A. Arnold, D.N. Appel, and C.M. Kenerley. 2000. Measurement of apple root losses associated with cold storage and elutriation of soil core samples. HortTechnology 10:580-584.

Wheeler, N.C. 1987. Effect of paclobutrazol on douglas fir and loblolly pine. J. Hort. Sci. 62:101-106.

Williams, D.R., B.M. Potts, and P.J. Smethurst. 2003. Promotion of flowering in Eucalyptus nitens by paclobutrazol was enhanced by nitrogen fertilizer. Can. J. For. Res. 33:74-81. 